\title{
First cultivation of Agaricus flocculosipes and a novel Thai strain of $A$. subrufescens
}

\author{
Thongklang $\mathrm{N}^{1,2}$, Sysouphanthong $\mathrm{P}^{3}$, Callac $\mathrm{P}^{4}$ and Hyde $\mathrm{KD}^{1,2}$ \\ ${ }^{1}$ School of Science, Mae Fah Luang University, Chiang Rai 57100, Thailand \\ ${ }^{2}$ Institute of Excellence in Fungal Research, and School of Science, Mae Fah Luang University, Chiang Rai 57100, \\ Thailand \\ ${ }^{3}$ Key Laboratory for Plant Diversity and Biogeography of East Asia, Kunming Institute of Botany, Chinese Academy of \\ Science, Kunming 650201, Yunnan, China \\ ${ }^{4}$ UR 1264, Mycologie et Sécurité des Aliments, 33883 Villenave d' Ornon, France
}

Thongklang N, Sysouphanthong P, Callac P, Hyde KD 2014 - First cultivation of Agaricus flocculosipes and a novel Thai strain of A. subrufescens. Mycosphere 5(6), 814-820, Doi 10.5943/mycosphere/5/6/11

\begin{abstract}
Agaricus flocculosipes and A. subrufescens are edible species that belong to section Arvenses of the genus Agaricus. Agaricus subrufescens (almond mushroom) is known to produce bioactive compounds with medicinal properties, such as anti-cancer and anti-tumor activity and fruiting bodies are also edible and nutritious. Agaricus subrufescens is presently cultivated in Brazil, China, Japan, Taiwan and some European countries for use as foods and nutraceuticals. Agaricus flocculosipes is a newly described species currently known only from Thailand, Mayotte Island and China. Species of Agaricus have high potential for cultivation as many species are edible and have medicinal properties. Herein we report the first cultivation of A. flocculosipes and a Thai strain of $A$. subrufescens. The strains were isolated from wild sporocarps and subcultured on compost extract agar medium. Standard compost based on wheat straw and horse manure was used as the cultivation substrate. A comparative study of the cultivation of one strain of A. flocculosipes and two strains of $A$. subrufescens from France and Thailand was carried out with four replicates trays. The mushroom spawn was inoculated into the compost and incubated at $25^{\circ} \mathrm{C}$. The mycelia fully covered and grew throughout the media after incubation for two weeks. A casing layer made up of sand, peat and lime (1:1:1) was applied. Fruiting phase was performed at $25{ }^{\circ} \mathrm{C}$ and $95 \%$ humidity. The first primordia of the French and Thai strains of A. subrufescens occurred after the casing layer was added at days 12 and 24, respectively. Yields were obtained from both strains of A. subrufescens. The yield of the Thai strain $\left(85.90 \pm 27.06 \mathrm{~g} \mathrm{~kg}^{-1}\right)$ was lower than that of the French strain $\left(178.56 \pm 68.28 \mathrm{~g} \mathrm{~kg}^{-1}\right)$ in the first production cycle lasting 34 days. The first primordia of $A$. flocculosipes formed at day 32 after casing, and the strain produced only a few fruit bodies $\left(1.04 \pm 0.95 \mathrm{~g} \mathrm{~kg}^{-1}\right)$. Further research is needed to develop suitable agriculture wastes and regimes for growing these mushrooms and for increasing production yields so that these strains and species can be industrialized.
\end{abstract}

Keywords - Agaricus - edible mushroom - fruiting test - mushroom growing 


\section{Introduction}

Most of edible mushrooms are macrofungi belonging to the phylum basidiomycota. Since ancient times mushrooms have been consumed by humans, not only as part of the normal diet but also as a delicacy because they have a high source of protein, desirable taste, aroma and also have medicinal properties (Zhong \& Tang 2004, Firenzuoli et al. 2008, De Silva et al. 2012a, 2012b, 2013).

Agaricus is probably the most important and potentially cultivatable genus, as most species are edible, some are delicious and widely consumed and others have considerable medicinal properties. Agaricus bisporus (the button mushroom) was first domesticated in France in 1650 (Atkins 1978, Patel 2013). Agaricus bisporus is very popular worldwide and is the most widely cultivated species of edible mushroom, accounting for $31.8 \%$ of the world market. Species of Lentinus are second ranking and species of Pleurotus are third ranking in the world market (Chang 1999).

Agaricus subrufescens is also a cultivated mushroom (Firenzuoli et al. 2008) with significant medicinal properties and belonging to the section Arvenses of the genus Agaricus, while Agaricus bisporus belongs to Agaricus section Bivelares (Kerrigan et al. 2008, Parra 2013). This mushroom is cultivated commercially in Brazil, China, Japan and Taiwan (Kerrigan 2005). Main synonyms of $A$. subrufescens are A. blazei sensu Heinemann (misapplied), A. braziliensis (illegitimate), and A. rufotegulis. This species has a broad climatic and geographical distribution range (Asia, Europe and Oceania). Recently Thongklang et al. (2014) showed that samples from Brazil, France and Thailand are amphithallic and interfertile.

Wild edible mushrooms in the section Arvenses include Agaricus arvensis, A. augustus and A. silvicola, all of which are collected from the wild for human consumption in Europe and Americas (Kalač \& Svoboda 2000, Wisitrassameewong et al. 2012). Zhao et al. (2012) described a new species in the section Arvenses of the genus Agaricus from Thailand as A. flocculosipes; this new mushroom is potentially cultivatable and is expected to be a good edible species that may have potential commercial value for Thailand and other countries.

Approximately 30,000 mushrooms throughout the world have been described (Kirk et al. 2008), and in Thailand 22 species are cultivated commercially for the Thai market (Thawthong et al. 2014). Our studies of basidiomycetes from northern of Thailand have reported several new species for Thailand. A new wild edible mushroom has been cultivated successfully; Pleurotus giganteus can form fruiting bodies at $25^{\circ} \mathrm{c}$ and has the possibility of being grown in Thailand (Klomklung et al. 2012).

Agaricus flocculosipes and Agaricus subrufescens are newly recorded or described species in Thailand. A flocculosipes is also recorded from Mayotte Island (Zhao et al. 2012) and China (Gui et al. 2014, in press). In Thailand, we questioned local people and found that these wild species are not commonly consumed and not many people are aware that these mushrooms are likely edible. These mushrooms could be introduced to Thai market for cultivation and medicinal use.

The objective of this study was to determine ways to cultivate the Thai mushroom strains of section Arvenses (A. flocculosipes and A. subrufescens) on a laboratory scale using compost. Research was directed towards the cultivation of these wild strains for fruiting competence, and we discuss the possible introduction to the local market.

\section{Materials \& Methods}

\section{Mushroom strains}

We collected numerous species of Agaricus between 2004 and 2013; some are potentially cultivatable and have medicinal properties. We isolated several Thai strains of A. flocculosipes and A. subrufescens from northern Thailand for potential cultivation. These species belong to section Arvenses, whose species are generally edible. Agaricus subrufescens (CA918= MFLUCC 11-0653) was found growing in a grassland at Mae Fah Luang University, Thailand by S.C. Karunarathna, P. 
Callac and S. Rapior in 2011. Agaricus flocculosipes (CA917, MFLUCC 11-0652) was also found along with CA918 on the campus of Mae Fah Luang University, Thailand by S.C. Karunarathna, P. Callac and S. Rapior in 2011. Mycelia were isolated and subcultured on compost agar medium. The strains were incubated at $25^{\circ} \mathrm{C}$ for two or three weeks.

\section{Spawn production}

Spawn is the media for transfer of the mushroom mycelium to the growing substrate for upscale production of mycelia for cultivation. Rye grain spawn prepared by Euromycel, France was used for spawn production (Navarro \& Savoie 2013, Llarena-Hernández et al. 2014). The spawn boxes containing $100 \mathrm{~g}$ of rye grain were inoculated with a half colony from actively growing mycelia of a $9 \mathrm{~mm}$ diameter Petri dish.

\section{Compost and casing layer}

Commercial compost based on horse manure mixed with wheat straw and with various additives as the main substrate for A. bisporus cultivation was provided by SA Renault, Pons, France. The substrate, compost $(8 \mathrm{~kg})$ was inoculated with spawn ( $2 \%$ weight of compost) and incubated at $25{ }^{\circ} \mathrm{C}$ and $85 \%$ humidity for 15 days. After the mycelia fully covered and grew throughout the compost, a casing layer was applied. The casing layer, made up of a mixture of limestone: peat: thin sand (1:1:1), was added ( about $4 \mathrm{~cm}$ deep) above the colonized mycelium in the compost, then incubated at $25{ }^{\circ} \mathrm{C}$ and $95 \%$ humidity and low $\mathrm{CO}_{2}$ concentration (LlarenaHernández et al. 2011, 2014). After casing, the trays were watered once a day. The fruiting test was carried out with four replicates trays (Royse 2010, Llarena-Hernández et al. 2011).

\section{Yield data and Statistical analysis}

The fruiting bodies, including those with open and closed caps, were manually harvested, and counted and weighed daily. The mushroom yields were recorded for 34 days. Yield data means total weight of fresh mushroom in one crop per kilogram of substrate (Royse 2010, LlarenaHernández et al. 2011). The data set was analyzed statistically for variance and mean by one-way ANOVA analysis using Duncan's multiple range tests. Differences were considered significant for $\mathrm{P}<0.05$.

\section{Results}

\section{Agaricus subrufescens}

A comparative study of the cultivation of the Thai and French strains of A. subrufescens was carried out with four replicates trays. Fruiting bodies of the Thai strain were produced at $25{ }^{\circ} \mathrm{C}$ and $95 \%$ humidity. The first primordia of the French A. subrufescens strain appeared on day 12 (Fig 1 e-f), while that of the Thai A. subrufescens strain appeared on day 24 (Fig 1 a-b), after casing was applied. Although yields were obtained for both strains, the yield of the Thai strain was lower than that of the French control strain, with the average wet yield of French and Thai strains $1,428.50 \mathrm{~g}$ and $687.17 \mathrm{~g}$, respectively (Table 1). We found that the A. subrufescens French strain produced 323 fruiting bodies in production cycle (34 days), while Thai strain produced 158 fruiting bodies in the production cycle (34 days). Comparison of Thai A. subrufescens and French strain production are given in Table 1 .

\section{Agaricus flocculosipes}

Cultivation of the Thai strain of Agaricus flocculosipes was achieved, but with low yield and in some trays, no yield. The mycelia of A.flocculosipes fully covered and grew throughout the culture substrate after 2 weeks incubation. The first primordia of A. flocculosipes formed on day 32 after casing (Fig $1 \mathrm{c}-\mathrm{d}$ ). The average wet yield of $A$. flocculosipes was $8.33 \mathrm{~g}$, with two fruiting bodies produced in 34 days (Table1). 

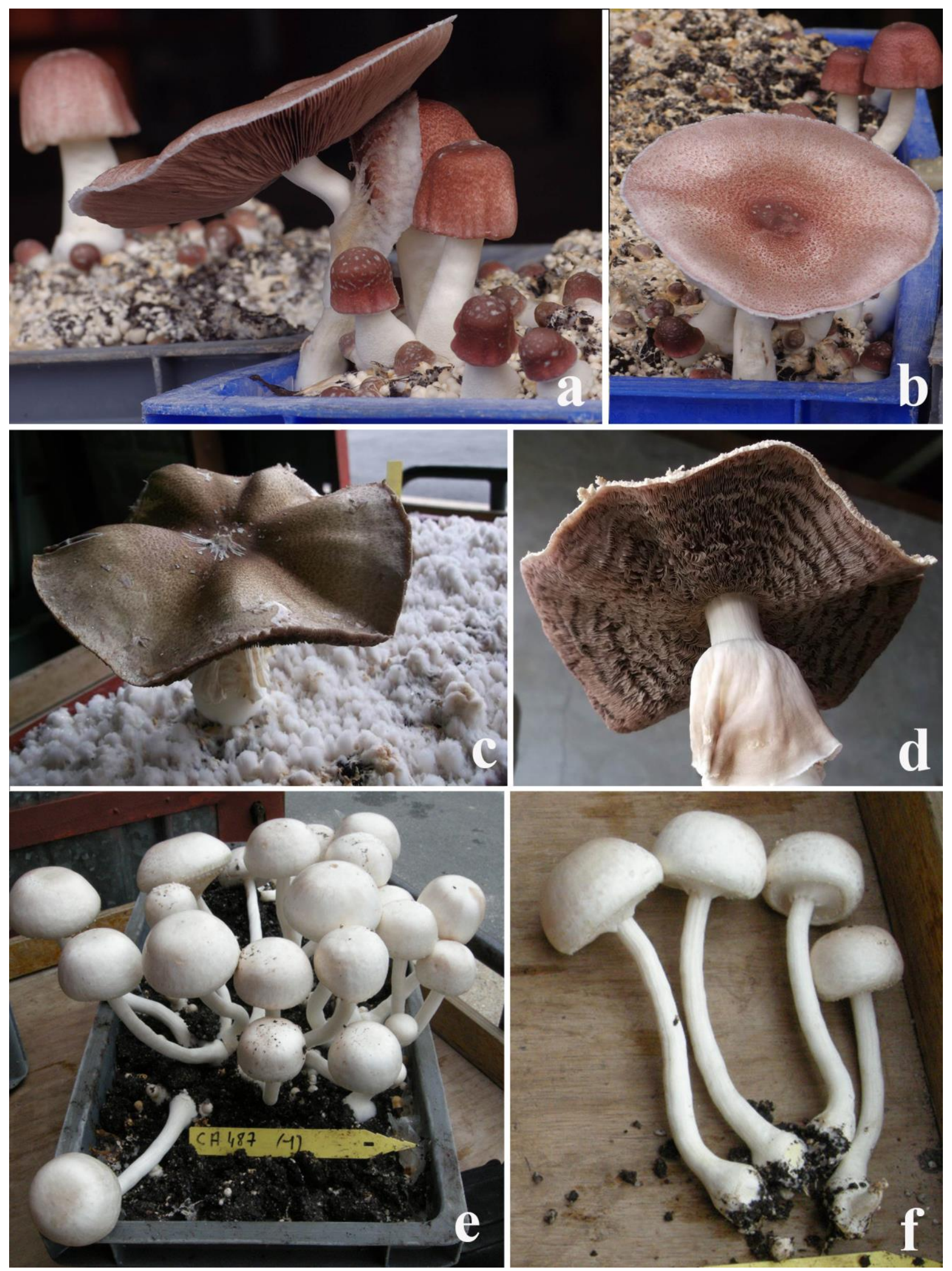

Fig. 1 - Cultivation of species of Agaricus. a-b: A. subrufescens Thai strain (CA918) produced at $25{ }^{\circ} \mathrm{C}$ and $95 \%$ humidity, c-d: A. flocculosipes (CA917) developing on compost media at $25{ }^{\circ} \mathrm{C}$ and 95\% humidity, e-f: French strain of A. subrufescens (CA487). 


\section{Confirmation of cultivated species}

The Thai strain of $A$. subrufescens that fruited at $25{ }^{\circ} \mathrm{C}$ and $95 \%$ humidity was checked to confirm the species. The macromorphological characters traits of this species are described in detail; the pileus surface covered with silk-like fibres and small scales, a reddish-brown cap, the odour of almond, a two-layered and floccose annulus, yellow staining when cut and a positive Schäffer's reaction all are typical of $A$. subrufescens.

The fruiting bodies of $A$. flocculosipes that grew on compost were confirmed as being the same species as the inoculated strain. The floccose stipe, almond odour, well-developed squamules on the pileus, two-layered annulus, and catenulate cheilocystidia were typical of the species.

Table 1 Comparison first cycle yields (34 days) Thai and French strains of Agaricus subrufescens.

\begin{tabular}{lccc}
\hline Contents & $\begin{array}{c}\text { Agaricus flocculosipes } \\
\text { Thai strain (CA917) }\end{array}$ & $\begin{array}{c}\text { Agaricus subrufescens } \\
\text { Thai strain (CA918) }\end{array}$ & $\begin{array}{c}\text { French strain } \\
\text { (CA487) }\end{array}$ \\
\hline $\begin{array}{l}\text { Occurrence of primordia after soil } \\
\text { casing }\end{array}$ & $30-32$ days & $21-24$ days & $7-14$ days \\
$\begin{array}{l}\text { Average wet weight } \\
\text { Yield data* }\end{array}$ & $8.33 \mathrm{~g}$ & $687.17 \mathrm{~g}$ & $1428.50 \mathrm{~g}$ \\
Number of fruiting bodies & $1.04 \mathrm{~g} \mathrm{~kg}^{-1}$ & $85.90 \mathrm{~g} \mathrm{~kg}^{-1}$ & $178.56 \mathrm{~g} \mathrm{~kg}^{-1}$ \\
158 & 2 & 158 \\
\hline
\end{tabular}

*Yield data $=$ total weight of mushroom per kilogram of substrate.

\section{Discussion}

Although there are well over 300 genera of mushrooms, only a few species are cultivated commercially due to the fact that some are mycorrhizal and apparently will not fruit without the host roots being present (Egli 2011). However, there are many saprobic genera, and these have the possibility of being cultivated (Klomklung et al. 2012, Thawthong et al. 2014). A simple fruiting test using wild strains is essential for testing cultivars that might be introduced to the market. The general methodology for assessing fruiting ability have been described, firstly the strains were isolated and inoculated to grain spawn and finally compost inoculation and casing with soil (Carrera et al. 2001, Coello-Castillo et al. 2009, Llarena-Hernández et al. 2011). Preparation of substrates suitable for Agaricus fruiting involves using standard compost and success in fruiting tests to predict whether it is possible to grow the wild strains (Llarena-Hernández et al. 2011, Navarro \& Savoie 2013, Thawthong et al. 2014).

Agaricus has high potential for cultivation as many of the species in this genus are edible and some have medicinal properties (Bernardshaw et al. 2005, Adams et al. 2008, De Silva et al. 2012a, 2012b, Wisitrassameewong et al. 2012). In this study we tested a new Thai strain of $A$. subrufescens and the new species, A. flocculosipes (section Arvenses) for fruiting competence. The two strains were isolated by tissue culture and as tropical strains, incubated at $25{ }^{\circ} \mathrm{C}$ (LlarenaHernández et al. 2011, 2014, Navarro \& Savoie 2013). Colony morphology on agar plates depended on the species of mushroom. The mycelia of all strains are white and have an almond odour during both spawn production and on compost media agar.

In fruiting trials of the Thai and French A. subrufescens strains, yields of the Thai strain were lower than the French strains; the productivity of the Thai strain was low $(85.90 \pm 27.06 \mathrm{~g}$ $\mathrm{kg}^{1}$ ), while the French strain was $178.56 \pm 68.28 \mathrm{~g} \mathrm{~kg}^{-1}$. Agaricus subrufescens cultivation trials by Llarena-Hernández et al. (2011) showed that wild strains [of A. subrufescens] produced a wide range of mushroom yields, depending on the mushroom species and strains. The Brazilian wild strain of $A$. subrufescens (WC837) that grew with wheat and horse manure as main substrate had a yield of $41.9 \pm 12.2 \mathrm{~g} \mathrm{~kg}^{-1}$, which is lower than our Thai strain corrected, while a French strain of $A$. subrufescens (CA487) had a yield of $207.9 \pm 47.9 \mathrm{~g} \mathrm{~kg}^{-1}$. The yield of the mushroom is dependent on the substrate used for cultivation. Eira (2003) used various local substrates for Agaricus subrufescens (as A. blazei) cultivation in Brazil; the yields of this mushroom ranged from 3 to 25 $\mathrm{kg}$ of fresh mushroom /100 kg of substrate (Eira 2003), depending on the substrate used. 
Agaricus flocculosipes is a new potential cultivable species in the section Arvenses described by Zhao et al. (2012). This species produced fruiting bodies but yields were low, although the mycelium has the ability to colonize well throughout the compost media, and the fruiting period was shorter when compared with the French and Thai strains of A. subrufescens. Further work will be carried out to develop suitable media for culturing these taxa, and genetic improvement will be attempted by breeding for increasing yield (Thongklang et al. 2014).

Normally, the time to fruiting and thus mushroom harvesting begins 15-20 days after casing. In this study, we found that French strain of $A$. subrufescens began to fruit 12 days after the casing layer was applied, while fruiting of the Thai wild A. subrufescens strain occurred 24 days after casing. Agaricus flocculosipes began to produce fruiting bodies at 32 days. However, the time of first fruiting is dependent on the material and method of casing. Llarena-Hernández et al. (2014) reported that increasing the depth of the casing layer applied to compost significantly improved yield and fruiting time in A. subrufescens. However further work will be carried out to develop suitable conditions for improving time to fruiting.

\section{Acknowledgements}

This work was supported by the Royal Golden Jubilee Ph.D. Program-RGJ-I (PHD / 0061 / 2552, 4. S. MF/52/A.1), and the Thailand Research Fund grant (BRG 5580009) under the research grant entitled "Taxonomy, Phylogeny and Biochemistry of Thai Basidiomycetes" for financial support. We thank to Institut National de la Recherche Agronomique (INRA), France and School of Science, Mae Fah Luang University is acknowledged for providing facilities and training.

\section{References}

Adams LS, Phung S, Wu X, Ki L, Chen S. 2008 - White button mushroom (Agaricus bisporus) exhibits antiproliferative and proapoptotic properties and inhibits prostate tumor growth in athymic mice. Nutrition and Cancer 60(6), 744-756.

Atkins FC. 1978 - Guide to Mushroom Growing. Queen Square, London.

Bernardshaw S, Johnson E, Hetland G. 2005 - An extract of the mushroom Agaricus blazei Murrill administered orally protects against systemic Streptpcoccus pneumoniae infection in mice. Scandinavian Journal of Immunology 62, 393-398.

Carrera DM, Bonilla M, Martínez W, Sobal M, Aguilar A, González EP. 2001 - Characterisation and cultivation of wild Agaricus species from Mexico. Micología Aplicada International 13(1), 9-24.

Chang ST. 1999 - World production of cultivated edible and medicinal mushrooms in 1997 with emphasis on Lentinus edodes (Berk.) Sing. in China. International Journal Medicinal Mushrooms 1, 291-300.

Coello-Castillo MM, Sánchez JE, Royse DJ. 2009 - Production of Agaricus bisporus on substrates pre-colonized by Scytalidium thermophilum and supplemented at casing with protein-rich supplements. Bioresource Technology 100(19), 4488-4492.

De Silva DD, Rapior S, Fons F, Bahkali AH, Hyde KD. 2012a - Medicinal mushrooms in supportive cancer therapies: an approach to anti-cancer effects and putative mechanism of action. Fungal Diversity 55, 1-35.

De Silva DD, Rapior S, Hyde KD. 2012b - Medicinal mushrooms in prevention and control of diabetes mellitus. Fungal Diversity 56, 1-29.

De Silva DD, Rapior S, Sudarman E, Stadler M, Xu J, Alias A, Hyde KD. 2013 - Bioactive metabolites from macrofungi: ethnopharmacology, biological activities and chemistry. Fungal Diversity 62, 1-40.

Egli S. 2011 - Mycorrhizal mushroom diversity and productivity - an indicator of forest health?. Annals of Forest Science 68, 81-88.

Eira AF. 2003 - Cultivo Do Cogumelo Medicinal Agaricus blazei (Murrill) ss Heinemann ou Agaricus brasiliensis (Wasser et al.), Viosa. Editora Aprenda Facil. 
Firenzuoli F, Gori L, Lombardo G. 2008 - The medicinal mushroom Agaricus blazei Murrill: Review of literature and pharmaco-toxicological problems. Evidence-Based Complementary and Alternative Medicine 5(1), 3-15.

Gui Y, Zhu GS, Callac P, Hyde KD, Parra LA, Chen J, Yang TJ, Huang WB, Gong GL, Liu ZY. 2014 - Agaricus section Arvenses: three new species in highland subtropical Southwest China. Fungal Biology, doi 10.1016/j.funbio.2014.10.005 (In press).

Kalač P, Svoboda L. 2000 - A review of trace element concentrations in edible Mushrooms. Food Chemistry 69, 273-281.

Kerrigan RW. 2005 - Agaricus subrufescens, a cultivated edible and medicinal mushroom, and its synonyms. Mycologia 100, 876-892.

Kerrigan RW, Callac P, Parra LA. 2008 - New and rare taxa in Agaricus section Bivelares (Duploannulati). Mycologia 100(6), 876-892.

Kirk PM, Cannon PF, Minter DW, Stalpers JA. 2008 - Dictionary of the fungi (10th ed). Trowbride, UK: CAB international, Cromwell Press.

Klomklung N, Karunarathna SC, Chukeatirote E, Hyde KD. 2012 - Domestication of wild strain of Pleurotus giganteus. Sydowia 60(30), 39-53.

Llarena-Hernández RC, Largeteau M, Farnet AM, Minvielle N, Regnault-Roger C, Savoie JM. 2011 - Phenotypic variability in cultivars and wild strains of Agaricus brasiliensis and Agaricus subrufescens; 7th International Mushroom biology and mushroom products Conference, INRA, Bordeaux, France.

Llarena-Hernández CR, Largeteau ML, Ferrer N, Regnault-Roger C, Savoie JM. 2014 Optimization of the cultivation conditions for mushroom production with European wild strains of Agaricus subrufescens and Brazilian cultivars. Journal of the Science of Food and Agriculture 94(1), 77-84.

Navarro P, Savoie JM. 2013 - Note: Selected wild strains of Agaricus bisporus produce high yields of mushrooms at $25^{\circ} \mathrm{C}$. Revista Iberoamericana de Micología, doi 10.1016/j.riam.2013.05.014.

Patel S. 2013 - Mushroom cultivation. In: Quest, 1(2) (eds K Pawar, H Patel, A Mishra). Gujarat, India: ARIBAS, pp.11-15.

Parra LA. 2013 - Agaricus L. Allopsalliota Nauta \& Bas. (Part II): Fungi Europaei. Alassio: Edizioni Candusso.

Royse DJ. 2010 - Effects of fragmentation, supplementation and the addition of phase II compost to 2nd break compost on mushroom (Agaricus bisporus) yield. Bioresource Technology 101, $188-192$.

Thawthong A, Karunarathna SC, Thongklang N, Chukeatirote E, Kakumyam P, Chamyuang S, Rizal LM, Mortimer PE, Xu J, Callac P, Hyde KD. 2014 - Discovering and domesticating wild tropical cultivatable mushrooms. Chiang Mai Journal of Science 41(4), 1-34.

Thongklang N, Hoang E, Rodriguez Estrada A E, Sysouphanthong P, Moinard M, Hyde KD, Kerrigan RW, Foulongne-Oriol M, Callac P. 2014 - Evidence for broad geographical hybridization potential among Agaricus subrufescens amphithallic isolates from Brazil, France and Thailand. Fungal Biology 118, 1013-1023.

Wisitrassameewong K, Karunarathna SC, Thongklang N, Zhao RL, Callac P, Moukha S, Ferandon C, Chukeatirote E, Hyde KD. 2012 - Agaricus subrufescens: A review. Saudi Journal of Biological Sciences 19(2), 131-146.

Zhao RL, Hyde KD, Desjardin DE, Raspé O, Soytong K, Guinberteau J, Karunarathna SC, Callac P. 2012 - Agaricus flocculosipes sp. nov., a new potentially cultivatable species from the palaeotropics. Mycoscience 53(4), 300-311.

Zhong JJ, Tang YJ. 2004 - Submerged cultivation of medicinal mushrooms for production of valuable bioactive metabolites. Advances in Biochemical Engineering/Biotechnology 87, 2559. 